\title{
Reflection of Legal Philosophy in Industrial Society
}

\author{
Nunik Nurhayati ${ }^{1 \mathrm{a}}$, Absori $^{1 \mathrm{~b}}$, Rohmad Suryadi ${ }^{2 \mathrm{c}}$ \\ ${ }^{1}$ Faculty of Law, Universitas Muhammadiyah Surakarta (UMS), Indonesia \\ ${ }^{2}$ Faculty of Communication and Informatics, Universitas Muhammadiyah Surakarta (UMS) Indonesia \\ ann123@ums.ac.id, ${ }^{\mathrm{b}}$ abs154@ums.ac.id, ${ }^{\mathrm{c}}$ rohmadsuryadi85@gmail.com
}

\begin{abstract}
This article aims to discuss the reflection of legal philosophy in industrial society and the legal concept that can bring Indonesian people into the third wave characterized by civilized industrial societies. The research method used in this paper is library research. Indonesia's transformation from an agrarian country to an industrial country turned out to still have many negative impacts. Industrialization causes serious problems in the form of dehumanization because one of the formal values of industrial society is the bureaucracy, in which other values such as routines, certainty, and instrumentalism are made which make a person in a position without choice and fatalistic. That is, the progress of the industry does not necessarily provide a solution to the problem, it could even be the existence of the industry to be the origin of the negative impact that occurred. The philosophy of modern law has proven to be unable to solve this fundamental problem. An alternative to explore the philosophy of law based on transcendental values comes as an answer by looking at the fact that sociologically Indonesian people still hold tightly to religious values and local wisdom to be used as a guide to solving their life problems. The most important indicator is the occurrence of balance in the industrial community so as to minimize social inequality that occurs between capital owners and workers.
\end{abstract}

Keywords-legal philosophy; industrial society; transcendental justice.

\section{INTRODUCTION}

Socrates, a Greek philosopher, stated that philosophy was not an activity that provided definite answers to everything. But philosophy is an activity that questions answers to something. Therefore, philosophy is universal, speculative, concerned with value, critical, and implicative. In its universal nature, philosophical thinking encompasses all aspects of science that exist in human life without exception. Philosophy is speculative because the problems faced go beyond the ingenious pressure on things that are beyond current knowledge, such as happiness, justice, and prosperity. Philosophy is related to value because philosophical issues are closely related to decisions about moral judgments, aesthetic, religious and social judgments. The critical nature of philosophy is shown by a critical analysis of concepts and meanings which are usually taken for granted by scientists without critical examination, through a process of radical thinking. While the implicative nature is shown if a philosophical problem produces answers that contain further consequences that touch the interests of life for humans.

Philosophical activity is a deep reflection to get to the point. In legal philosophy, there is an activity of reflective thinking about the law as a symptom that is expressed by humans. Legal philosophy wants to find the nature of law, knowing what is actually behind legal norms, seeking what is hidden within the law, investigating legal norms as a consideration of the value and postulate of law, to the investigation of the final basis.

In the process of reflective thinking, legal philosophy produces a variety of streams which later become the basis for law enforcement in all fields that are arranged both from the classical period to the contemporary period. There are various streams of legal philosophy from the classical to modern times that developed in the western world such as the Natural Law School, the Law Positivism Flow, Utilitarianism, Historical History, Sociological Jurisprudence and Legal Realism. In Indonesia also develops contemporary law such as Progressive Legal Theory, Developmental Law Theory, Integrative Legal Theory and Transcendental Value-Based Legal Theory which is being developed by legal experts in Indonesia.

However, specifically there is still one aspect of legal philosophy that has not received much attention specifically in the realm of industrial law. While the development of the science of society today is moving towards industrialization which is characterized by an industrial revolution from traditional society to modern society accompanied by the development of science and technology. This situation resulted in the characterization of the characteristics of modern science, with the following characteristics [1]:

a. Based on the positivism paradigm. This characteristic can be seen from the development of science and technology that does not pay attention to aspects of both ethical and religious values, because indeed one of the axioms of positivism is value free which encourages the growth of the principles of science for science.

b. Encouraging the growth of hedonism and consumerism. Various developments in science and technology always refer to efforts to increase the enjoyment of life, even though it can encourage the 
loss of human spirit due to the increasingly popular culture of consumerism which continues to be fostered by the media of modern technology such as large-scale advertising that can create false needs which Herbert Marcuse defined as false consciousness in the form of the needs that are implanted into each individual for the sake of certain social interests in its repression.

c. The development is very fast. The achievement of modern science and technology shows amazing acceleration, changes not in an annual time, maybe even in a matter of days, this is clearly very different from the development of previous science and technology which according to Alfin Tofler from the first wave (agricultural revolution) took thousands of years to reach the second wave (industrial revolution), where as it is known that the wave occurred due to the achievement of science and technology.

d. Being exploitative of the environment. Various environmental damage today is inseparable from the achievement of science and technology that lacks attention to environmental impacts.

Industrialization has brought tremendous social change for modern society, especially now that it has surpassed the third wave of post-production production based on new principles that emphasize more value for a better, more civilized and democratic future.[2] Then the question then arises how is the basis of legal philosophy in industrial society in Indonesia and What is the paradigm of the philosophy of transcendental law characterized by civilized industrial society?

\section{RESEARCH METHOD}

This research includes doctrinal legal research by conducting study of documents relating to the legal philosophy and development of industrial society in Indonesia. The legal concept used in this study is the law is the principle of truth and justice that is natural and universal. Normative legal research not field research because what is examined is legal material, so it can be said to be a library based, focusing on reading, and analyzing the primary and second materials. [3] In this study using research source collection techniques in the form of library research techniques.

\section{RESULT AND DISCUSSION}

\section{A. The Base of Legal Philosophy in Industrial Policies in Indonesia}

According to Indonesian Muslim Scholar, Nur Cholis Madjid, Industrialization causes serious problems in the form of dehumanization. [4] According to him, one of the formal values of industrial society is the bureaucracy, which includes other values such as routines, certainty, and instrumentalism. The mechanism makes someone in a position without choice, becomes fatalistic. That means that someone has lost himself. It is only a function of a whole machine, which when standing alone, or alone, will have no meaning. It is used or discarded solely on the basis of functions that it might do. While its intrinsic humanity is often not counted.

The same thing was also expressed by Karl Polanyi who revealed that industrialization in the production process caused a double movement. On the one hand it causes the middle class to achieve prosperity because job opportunities for business interests can advance, investment develops. However, on the other hand, the merchant class and workers do not have organs to find danger that arises from the exploitation of physical labor, destruction of family life, destruction of the surrounding environment, deforestation, pollution of the river setback of standards of expertise, disruption of traditional culture, widespread decline of existence including housing and art, as well as various forms of private and public life that have no effect on business profits. [5]

So, according to Nur Cholis Madjid there are two values held by someone in industrial society. First, the official during work time and second, the unofficial during free time. It can also be said that official values are norms in public life and underground values are the norm in private life. Formal values or public life are a form of one's sacrifice through work that will give him material material which he will later use in private life with his own values.

The philosophical solution of this problem according to Nur Cholis Majid by quoting the opinion of the figures of the critical paradigm Post Positivist flow, Herbert Marcuse is by controlling or restraining production. Marcuse argues that humanity has the core of freedom. So the loss of freedom, however it can be found justification, is to eliminate humanity. Indeed modern industrial society creates the possibility to develop a time that will give freedom to declare private life. But that development will also threaten existing interests. Because the greater the likelihood of someone freeing themselves from obstacles caused by poverty or deprivation, the more industrial society feels the necessity to maintain and sharpen these barriers, unless the established domination structure is destroyed. Then productivity must be restrained to provide a material basis for the implementation of private values that are more humane.

In the positivistic legal philosophy, the problems that occur in industrial society are solved by formal and systematic legal approaches. Industrialization has an impact on the rationalization of various systems without exception, and the legal system is included in the process. So the written legal regulations on industry in Indonesia have been made by the legislative and executive institutions as a form of state sovereignty to provide regulation, supervision and development for industries that stand on Indonesian land.

According to the positivistic figure, Hans Kelsen, the law must be cleansed from elements that are not legal, such as ethics. The law must be cleansed of morals, as taught by the natural law; also the concept of customary law (sociological) and the conception of justice (political element). According to him, law is a necessity, not as a 
reality. Law also has a hierarchical system, which is arranged from the lowest level to the highest rank. Lower law must be grounded, sourced, and must not contradict the law which is higher. Thus, the law according to Kelsen, is: first, a closed system or a pure legal system, namely a system of pure norms that must be separated from other elements that are not legal; second, law as a necessity (das sollen); law as a systematic ranking system according to certain requirements. [6]

The manifestation of Kelsen's opinion can be seen from the existence of Pancasila as a ground norm or basic norm that underlies the birth of the Indonesian State Constitution, especially article 33 which regulates the control of economic and industrial assets within the country. Then followed by the birth of a law that regulates industry within the scope of the Republic of Indonesia.

By looking at the roots of the values of the Indonesian people who have the principles of populist economy as stated in the 1945 Constitution article 33, on a regulation basis, industry as a sub-sector of the economy has the same direction or orientation as the populist economy that places state power to manage assets that control the lives of many people. and limit exploitation in industrial society.

Meanwhile, the paradigm of legal philosophy based on Transcendental Values as quoted by Absori from Kuntowijoyo's opinion is that values born of prophetic intellectuals are based on faith in Allah SWT as His word in the Qur'an Surat Ali Imron verse 110. Transcendental values that can help lift human civilization are through humanization (ta'muruna bil ma'ruf), liberation (tanhauna 'anil munkar) and transcendence (tu'minuna billah). [7]

These three bases of the philosophy of law paradigm will then be discussed further to discuss the legal concept that can bring Indonesian people into the third wave characterized by civilized industrial society.

\section{B. Transcendental Law Philosophy Paradigm in Civilized Industrial Communities}

The industrial era that began in the Industrial Revolution in England at the end of the 18th century with the invention of steam engine by James Watt's, gave rise to factories with the use of technology machines. The machine that was first made was a textile machine so that the production activities that originally used human power switched to mechanical power. This certainly has a positive impact in terms of economic efficiency in the production process but is able to produce a large number of products in a short time. But the negative impacts that emerged after the industrial revolution also existed, namely the growing urbanization in industrial cities that caused the population in the countryside (agriculture) to move to industrial cities to become factory workers.

The negative impact of course affected the emergence of unemployment and criminal acts due to intense competition, high work demands, minimum labor costs while the necessities of life in the city are very expensive. Not to mention the differentiation of the owners of capital and labor where economic disparities are increasingly seen when capital owners get richer and workers get poorer. Poor life and unhealthy habits due to the industrial revolution are what drives various kinds of crime and chaos. In addition, environmental damage began to be felt and realized by the world community as a result of production activities that exploited nature during the industrial revolution II and III.

The industrial revolution continues to this day into the Industrial Revolution IV (Industry 4.0). The 2018 World Economic Forum in Davos-Klosters, Switzerland, carries an important message about Industry 4.0 as a new chapter that will change all lines of human life through technological developments. Technological breakthroughs supporting Industry 4.0 include artificial intelligence (artificial intelligence), robotics development, "the Internet of Things",virtual reality, and three-dimensional printing machines. When compared with the previous transformation, Industry 4.0 occurs exponentially or extends, disrupting every industry in many countries, while promising transformation throughout the production and governance system. The revolution must be directed correctly by all parties so that the process of digitization that occurs can provide good for the future population.

Not finished solving the problem due to the negative impact of the first to third industrial revolution, the 4.0 industrial revolution has emerged which is predicted to also have a negative impact on humans. Industrial revolution, technological progress, ease of life and other positive impacts are certainly not expected to be in line with its negative impacts. So, it's time to initiate engineering as an effort to minimize the negative impact of the industrial revolution so that humans as human beings can become subjects who are able to control the emergence of negative impacts due to industrial activities.

According to the Positivism Law school philosophy figure, John Austin stated that the law was an order from the authorities; law is seen as an order from the person who holds the highest authority (sovereignty); law is a command that is charged to people who think who hold power. Law is also a closed and permanent logic. So the positive law must fulfill several elements, namely elements of orders, sanctions, obligations, and sovereignty. So, beyond that all is not law, but positive morality.

Hans Kelsen on his law theory, the Pure Theory of Law, provides the underlying similarity of law as HLA Hart tried to answer the question, "What is law?" However; it is not a question of "what is law supposed to be?" To put it clearly, Hart's perspective related to the question of "nature law" is different from the commands supported by threat is. [8]

Positivist opinions which tend to emphasize universal law are then opposed by post-positivist streams, especially critical streams which emphasize the law which has a critical paradigm in viewing industrial society. According to Somantri, the critical stream opposes positivism for various reasons.[9] First, positivism tends to see social life as a natural process. Critical theorists prefer to focus attention on human activities and on the ways these activities affect a wider social structure. While positivism is considered to ignore actors, lowering the actor to a passive degree is determined by natural strength. 
Because they are convinced of the peculiarities of the nature of actors, critical theorists cannot accept the idea that general law of science can be applied to human actions. Second, positivism is criticized for being complacent only by assessing tools such as written law to achieve certain goals, but not making a critical assessment of deviations from a goal. This criticism leads to the view that positivism is conservative in character, unable to challenge the system of industrial capitalism that tends to be exploitative.

The positivistic legal philosophy that has been regarded as progress in the western world, namely the philosophy of modern systematic law has proven to be unable to solve fundamental problems regarding the problem of dehumanization in industrial society. Even though the law should have been made by humans to make people prosperous. But what happens is that the law provides an opportunity to distort human happiness. Civilization that is increasingly developing requires the ability to develop as well. Philosophy as the root of science should be able to be explored more deeply so that the knowledge and products produced provide welfare for humans. The most important indicator is the occurrence of balance in the industrial community so as to minimize social inequality that occurs between capital owners and workers.

Legal experts Saint Louis School of Law, Petroski, began to question, "Is Post-Positivism Possible?". Could it be possible to shift positivist philosophy in the laws of modern society? Whereas the positivistic paradigm has been embedded in a set of rules that live in society in the current era of industrialization. In Petroski's opinion, there is a very open alternative paradigm that emerges from new investigations that produce meaningful practical implications.

"The conditions of production of legal and theoretical discourse make it profitable that something resembles what we now call legal positivism will always be part of legal theory, whether we choose to use that term or not. Those conditions frustrate aspirations for legal theory, but they also ensure the continued opening of new inquiries with potentially meaningful practical implications. " [10]

To break the impasse of the philosophical paradigm, an alternative to explore the philosophy of law based on values transcendental is present as an answer. Relation of religion to law in the face of changes in industrial society began to be widely studied by academics. As an alternative third paradigm after positivistic and post positivistic, the transcendental paradigm accommodates the spiritual moral paradigm in law enforcement. Said stated that based on religious values, the law provides protection for people who are under their authority. Community members give up their sovereign rights to protect themselves and submit them to law. Living in a community means protecting its members and mediating them with justice. At this point, religion plays a role not only to give an illusion to a society. But more urgently, religion through prophetic historical knowledge can be a driving force for the birth of a better society change.

"Law provides protection for those who come under its authority. They relinquish their sovereign right to protect themselves and surrender it to law. Living in a society entails protecting its members and arbitrating among them with justice. Law and religion should not be founded on human whims and illusions. Nor should they be based on their mental perceptions of the world; rather, our intellectuals should be creating a methodology using historical knowledge for weighing our perceptions, with harm and benefits to the creation as its point of reference. Our historical knowledge permits to shift through the harmony and benefits of countless human actions. [11]

Sociologically, Indonesian people still hold tightly to religious values in this case Islam as the majority and local wisdom to be used as guidelines for solving life's problems. This is also reflected in the values contained in Pancasila which prioritize the role of the state, society and law framed in religious values. It is not like secularism that is seen in western societies that are more concerned with individual freedom as long as it obeys only the country's written law. So digging into the paradigm of transcendental law becomes a matter of necessity and can add to the knowledge of science in the face of the problems of the Indonesian people who began to become Industrial societies.

In this context, reality in the modern era cannot be denied from the object of Islamic fiqh study. The progress of science and technology needs to be responded appropriately and relevant to the context. [12] When classical legal literature does not adequately address contemporary problems that continue to develop, it takes courage to carry out legal theoretical reformulation and methodological reconstruction that are more acceptable and able to solve the problem of industrial society humanistically.

So the effort of legal progress is considered as a necessity. Textual law is considered limited and has stagnated, while social reality and its problems are unlimited and continue to be sustainable. Limited legal texts are unlikely to be the only source of legislation against unlimited social reality. As in Kennedy's writing, these founders of sociology are believed to change in "industrial society" would be a constant, but that could be regulated, moderated and controlled. By whom? [13]

In other words, reformulation is an urgent matter in legal discovery. Because in the industrial society the dynamics continue to develop with a number of legal issues, so the need for legal legitimacy based on findings in reality that are in line with the value of transcendence. The term discovery of law (rechtsvinding) is considered by Syamsul Anwar to be more appropriate to be used in the context of a transcendental value-based law such as Islamic law, rather than law formation (rechtsvorming). This is because the mujtahid did not make, but found the law in the text (nash). In contrast to western law that was made by legislators.

This effort to find a law based on transcendental values must then be given space to solve various problems 
in today's industrial society. The effort to find the law based on transcendental values has been done by Muslim legal experts in Indonesia by using the philosophical foundation of the maqasid syari'ah developed by Asy Syatibi. From the beginning maqasid sharia as the basis for Islamic jurisprudence, in its development the study of maqasid shari'ah increasingly reveals its urgency in establishing Islamic law, especially in responding to contemporary legal problems.

In its time, maqasid sharia had found its conceptual building which had to be oriented towards the benefit of five basic principles (al-mabadi 'al-khamsah), namely protection of religion, soul, mind, property and descent. Maqasid studies are more perfect in the hands of Thahir Ibn Asyur, where the maqasid is not only understood as mabda '(principle) in ijtihad, but becomes muqtarabah (approach) in ijtihad. Ibn Asyur firmly said that the approaches of lafziyah's arguments were not enough to find Islamic law, but were complemented by a causative approach and a teleological approach. In addition, maqasid sharia no longer deals with the five basic aspects of human needs, but also universal values, such as tolerance, equality, democracy and human rights. [12]

\section{CONCLUSION}

The paradigm of legal philosophy both positivistic, post positivistic and finally transcendental law philosophy has provided a philosophical basis for the enforcement of the legal system in the world today. Positivistik with a formal legal approach, then post positivistic with a critical and transcendental paradigm with a spiritual spiritual value approach to the development of today's industrial society that began to develop in all corners of the world, including Indonesia.

In Indonesia, industrialization causes serious problems in the form of dehumanization. The transformation of Indonesia from an agrarian country into an industrial country turned out to still cause many negative impacts. An alternative to explore the philosophy of law based on transcendental values is present as an answer. the purpose of Islam with its various transcendent values comes to the creation of a more humanistic society, humanizing human beings. By realizing the balance of private life and public life in life. The most important indicator is the occurrence of balance in the industrial community so as to minimize social inequality that occurs between capital owners and workers.

\section{REFERENCES}

[1] M. Rakhmat, Pengantar Filsafat Hukum. Bandung: Warta Bagja, 2015.

[2] Alvin and H. Toffler, Mencipatakan Peradaban Baru; Politik Gelombang Ketiga. Yogyakarta: Ikon Literalitera, 2002.

[3] J. Ibrahim, Teori dan Metodologi Penelitian Hukum Normatif. Malang: Bayumedia Publishing, 2006.

[4] N. Madjid, "Masyarakat Industri dan Proses Dehumanisasi." [Online]. Available: http://nurcholishmadjid.org/assets/pdf/buku/1987_11Masyarakat-Industri-dan-Proses-Dehumanisasi.pdf. [Accessed: 13-Aug-2018].

[5] K. Polanyi, Transformasi Besar. Yogyakarta: Pustaka Pelajar, 2003.

[6] L. Rasyidi and B. A. Sidarta, Filsafat Hukum: Mazhab dan Refleksinya. Bandung: Remaja Rosdakarya, 1994.

[7] Absori, "Epistimologi dan legalisasi hukum transendental," in Hukum Transendental: Pengembangan dan Penegakan Hukum di Indonesia, 2018, pp. 23-33.

[8] K. Dimyati, Absori, K. Wardiono, and F. Hamdani, "Morality And Law: Critics upon H.L.A Hart's Moral Paradigm Epistemology Basis based on Prophetic Paradigm," Junal Din. Huk., vol. II, no. 1, pp. 23-30, 2017.

[9] E. D. Somantri, "Kritik Terhadap Paradigma Positivisme," J. Wawasan Huk., vol. 28, no. 1, 2013.

[10] K. Petroski, "Is Post- Positivism Possible?," Ger. Law J., vol. 12, no. 2, 2011.

[11] J. Said, "Law, Religion And The Prophetic Method Of Social Change Core," J. Law Relig. Cambridge, vol. 15, 2001.

[12] Maulidi, "Maqasid Syariah Sebagai Filsafat Hukum Islam," J. Al-Mazahib, vol. 3, no. 1, 2015.

[13] D. Kennedy, "Law and the political economy of the world," Leiden J. Int. Law, vol. 26, no. 1, pp. 7-48, 2013. 